Отримано: 20 листопада 2018 р.

Прорецензовано: 22 листопада 2018 р.

Прийнято до друку: 23 листопада 2018 р.

e-mail: huchto@ajp.edu.pl
Beata Uchto-Żywica. Psychologiczne aspekty chorób nowotworowych psychological aspects of cancer. Наукові записки Національного університету «Острозька академія». Серія «Психологія» : збірник наукових праџь. Острог : Вид-во НаУОА, листопад 2018. № 7. С. 122-127.

DOI: $10.25264 / 2415-7384-2018-7-122-127$

УДК: 159.99

Beata Uchto-Żywica,

doktor nauk o zdrowiu, psycholog, polonista.

Adiunkt w Katedrze Edukacji Dziecka w Akademii im. Jakuba z Paradyża w Gorzowie Wielkopolskim. Interesuje się zagadnieniami z zakresu historii psychiatrii i psychologii XIX wieku oraz Dwudziestoleciem Międzywojennym.

\title{
PSYCHOLOGICAL ASPECTS OF CANCER
}

This article presents the most important issues related to the psychological aspects of tumor disease. The strategies of dealing with the disease, psychological defense mechanisms, emotional reactions and the phase of adaptation to a difficult situation are discussed. The term subjective picture of the disease has been defined. In the second part psychological methods of supporting sick people and methods of psychotherapy has been discussed.

Key words: tumor disease, cancer, emotions, subjective picture of the disease.

\author{
Beata Uchto-Żywica, \\ doktor nauk o zdrowiu, psycholog, polonista. \\ Adiunkt w Katedrze Edukacji Dziecka w Akademii im. Jakuba z Paradyża w Gorzowie Wielkopolskim. Interesuje sie \\ zagadnieniami z zakresu historii psychiatrii i psychologii XIX wieku oraz Dwudziestoleciem Międzywojennym.
}

\section{PSYCHOLOGICZNE ASPEKTY CHORÓB NOWOTWOROWYCH}

W poniższym artykule zaprezentowano najważniejsze zagadnienia zwiąane z psychologicznymi aspektami choroby nowotworowej. Omówione zostały strategie radzenia sobie z choroba, psychologiczne mechanizmy obronne, reakcje emocjonalne i fazy adaptacji do trudnej sytuacji. Zdefiniowane zostało pojęcie subiektywnego obrazu choroby.

Stowa kluczowe: choroba nowotworowa, rak, emocje, subiektywny obraz choroby.

Wstęp. W poniższym artykule dokonano próby usystematyzowania aktualnej wiedzy na temat wybranych zagadnień z obszaru psychologii, dotyczących chorób nowotworowych. Podobnie jak w przypadku innych trudnych i nierzadko przewlekłych chorób, szczegółowo omówiono następujące po sobie etapy oswajania się z zaistniałą sytuacją zdrowotną, przedstawiono możliwe reakcje emocjonalne oraz występujące mechanizmy obronne. W holistycznym rozumieniu nowotwory dewastują i uszkadzają organizm w znaczeniu medycznym - jako jednostka chorobowa ale również angażują i wyczerpują zasoby psychiczne człowieka. Istotne zmiany zachodzą także w życiu rodzinnym nierzadko redefiniując podstawowe role rodzinne czy systemy wartości.

Psychologiczne reakcje na chorobę. Mianem nowotworu określa się tkankę rozrastającą się w organizmie, zakłócającą jego wewnętrzną ogólnoustrojową harmonię. Według współczesnych badaczy, pod nazwą «rak» znajduje się obecnie więcej niż 100 jednostek chorobowych, co wynika z ich wieloczynnikowej i nie zawsze jasnej etiologii ${ }^{1}$. Według klasyfikacji medycznej nowotwory zostały podzielone na rodzaje, a jednym z kryterium ich klasyfikacji jest występowanie przerzutów. Stąd też wyodrębniono nowotwory złośliwe, półzłośliwe oraz niezłośliwe.

b) Nowotwory n i e z ło ś 1 i w e: ich najistotniejszą cechą jest to, że nie powodują przerzutów. Są to więc najmniej groźne nowotwory (poza tymi, które zostały umiejscowione w okolicy centralnego układu nerwowego lub dużych naczyń), rosną powoli i tym samym można je szybko wyeliminować. Ich najważniejszą cechą jest to, że nie powodują nawrotów, a więc usunięcie ogniska choroby jest równoznaczne z jej końcem. Do nowotworów niezłośliwych zalicza się włókniaki, tłuszczaki, mięśniaki, itp. ${ }^{2}$.

c) Nowotwory z ło śl i w e ( $\mathrm{r} \mathrm{a} \mathrm{k} \mathrm{i,} \mathrm{m} \mathrm{i} \mathrm{ę} \mathrm{s} \mathrm{a} \mathrm{k} \mathrm{i} \mathrm{):} \mathrm{to} \mathrm{najgroźniejsza} \mathrm{odmiana} \mathrm{nowotworów.} \mathrm{Ich} \mathrm{zagroże-}$ nie wynika $z$ agresywności narastającej tkanki, naciskania na sąsiednie tkanki, szybkim rozwojem, wzrostem $i$ przede wszystkim - dawaniem przerzutów. To powoduje brak sukcesu w leczeniu i przegraną z chorobą w sytuacji, gdy zostanie wykryta zbyt późno. Do nowotworów złośliwych należą głównie raki nabłonkowe u dorosłych

\footnotetext{
1 M. Jabłoński, M. Furgał i in., Miejsce psychoonkologii we współczesnej psychiatrii, «Psychiatria Polska» 2008, t. XLII, nr 5, s. 749.

${ }^{2}$ J. Pawlęga , Medyczny obraz choroby nowotworowej [W:] D. Kubacka-Jasiecka (red.), Zmagając się z choroba nowotworo$w a$, s. 50.
} 
oraz mięsaki - nienabłonkowe głównie u dzieci, także białaczki³ .

d) Nowotwory p ó łz ł o śl 1 i w e: ich cechą charakterystyczną jest współwystępowanie cech zarówno nowotworów złośliwych jak i niezłośliwych. Dlatego istotna jest tu cecha nawracania np. w przypadku guza ślinianek czy szerzenie się odległych wszczepów w przypadku brodawczaków pęcherza moczowego $0^{4}$.

Trzeba również pamiętać, że choroba nowotworowa jest pewnym procesem o różnym przebiegu i czasie trwania, od momentu zachorowania tkanki to ujawnienia konkretnych objawów nowotworowych może upłynąć nawet od 15 do 30 lat $^{5}$.

Odkryty i zdiagnozowany nowotwór wywołuje wiele silnych oraz skrajnych emocji. Od paraliżującego lęku i strachu po głęboką nadzieję i wiarę w wyleczenie. Bez wątpienia rak zmienia całe życie chorego: wpływa na jego psychikę, rodzi wiele refleksji dotyczących życia, zmienia patrzenie na świat. Wiele osób, które wygrały z chorobą przyznaje, że zmieniła ona całkowicie ich życie. Każdy pacjent onkologiczny tworzy sobie pewne wyobrażenie na temat swojego stanu. Obraz choroby ogólnie - jest to złożony dynamiczny schemat poznawczy. Każdy pacjent ma swój własny - subiektywny obraz choroby, a więc swoją osobistą definicję danego schorzenia. Na tworzenie danego obrazu wpływa wiele czynników. Źródłem informacji jest przede wszystkim własne samopoczucie oraz objawy, które czuje pacjent i jest w stanie zaobserwować. Wiele informacji dostarczyć mogą osoby kompetentne - lekarze, pielęgniarki. Niestety źródłem wiedzy są także osoby niefachowe - rodzina, «dawni» pacjenci, a także media - prasa, telewizja, książki, internet. Wszystko to prowadzi do wytworzenia u chorego zbioru sądów, refleksji, emocji, poglądów i myśli dotyczących choroby i jej przebiegu. Dodatkowych emocji dostarczają nowe warunki życia oraz potrzeba hospitalizacji. Leczenie szpitalne jest sytuacją stresującą, wymaga dostosowania się do nowych zasad, ogranicza aktywność, pacjent czuje się zależny od innych. W wielu szpitalach pacjenci obawiają się także tego, jak będą traktowani, czy uszanuje się ich poczcie godności i indywidualności ${ }^{6}$. Często z takim obrazem - pesymistycznym i wyolbrzymionym - pacjent zostaje sam. Bez względu na to, czy są to informacje fałszywe czy prawdziwe - rodzą najbardziej realne i odczuwalne emocje. Chory przeżywa silny lęk przed nieznanym, identyfikuje się z innym pacjentem i może wiele wycierpieć. Należy pamiętać, że subiektywny obraz choroby u pacjenta ma olbrzymi wpływ na jego postawę wobec choroby, na jego podejście do leczenia, aktywność i tak istotną w tej chorobie - współpracę z personelem medycznym.

Wybitny znawca problemu - M. Jarosz (1983), szczegółowo opisał wszelkie najważniejsze aspekty obrazu własnej choroby. W związku z chorobą wyróżnił autor różne typy reakcji:

-Zaprzeczanie - to nieświadome wypieranie choroby, uznanie jej za niebyłej, nie przyjmowanie wiarygodnych i rzetelnych informacji.

- Pomniejszanie - to bagatelizowanie przez pacjenta jego choroby. Często spotykane u chorych na raka z uwagi na ogrom ich cierpień i niepewną przyszłość. Chorzy nie chcą wierzyć w oczywiste objawy i zaniżają ich wagę.

- Przyjęcie diagnozy - to akceptacja opinii lekarza, przyjęcie obrazu własnej choroby, oddanie się opiece lekarskiej.

- Wyolbrzymianie - przeciwnie do bagatelizowania - jest to przejaskrawianie własnej choroby i jej dolegliwości $\mathrm{i}^{7}$.

Choroba jest bardzo ważną częścią życia pacjenta i wprowadza w nim istotne zmiany. Po usłyszeniu diagnozy pacjent zazwyczaj musi się z nią oswoić i przyjąć odpowiednią strategię. Różne może być także znaczenie choroby dla chorego. Dla niektórych może być początkiem nowego etapu w życiu, pewnym punktem zwrotnym inicjującym kolejne zmiany. Dla innych jest największą traumą i upadkiem, z którego trudno się podnieść.

Uogólniając, można chorobę uznać jako:

2. Przeszkodę - bo rodzi to postawę walki i aktywności gdyż choroba uznana została jako wyzwanie i wróg, który należy pokonać.

3. Stratę - postrzeganie choroby jako wielkiego nieszczęścia w życiu, rodzi przygnębienie i lęk. Często związane jest $\mathrm{z}$ upośledzeniem czynności jakiegoś narządu, ze zniekształceniem lub z jego utratą w wyniku choroby.

4. Ulgę - choroba to usprawiedliwienie wobec siebie i innych, uwalnia od obowiązków i odpowiedzialności. Może rodzić bierność u pacjenta i szybkie pogodzenie się ze swoim losem.

5. Korzyść - choroba w tym przypadku jest dla pacjenta sposobem uzyskania wielu potrzeb, w tym potrzeby akceptacji i zainteresowania. Może być przez pacjenta przyjmowana jako wielki dar od losu.

6. Wartość - dla wielu pacjentów choroba oznacza ogromny przełom w ich życiu i może stać się wartością

${ }^{3}$ J. Pawlęga, Medyczny obraz choroby nowotworowej [W:] D. Kubacka-Jasiecka (red.), Zmagając się z choroba nowotworo$w a$, s. 50

${ }^{4}$ Tamże, s. 51.

${ }^{5}$ Tamże, s. 55.

${ }^{6}$ M. Bąk- Sosnowska, Choroba w życiu człowieka, [W] A. Trzcieniecka- Green (red.) «Psychologia. Podręcznik dla studentów kierunków medycznych», s. 190.

${ }^{7}$ M. Jarosz, Psychologia lekarska, s. 250. 
samą w sobie - rodzajem bohaterskiego cierpienia i dystansem wobec przyziemnych spraw ${ }^{8}$.

Jak zatem widać, cały kalejdoskop uczuć oraz refleksji i postaw dotyczących tej ciężkiej choroby mogą u pacjenta wyzwolić wybrane postawy i strategie oraz wzmocnić lub osłabić jego motywację do walki z chorobą. Według Jarosza można oczekiwać od pacjenta następujących postaw:

-Walka - występuje wtedy, gdy pacjent postrzega chorobę jako przeszkodę lub wroga, towarzyszy mu wówczas silna motywacja do wyleczenia oraz nastawienie na współpracę z lekarzem.

- Rezygnacja - jest to zbyt szybkie poddanie się chorobie, brak motywacji i chęci, współpracy z lekarzem. Bierność - rodzi się wtedy, gdy chorobę postrzega się jako stratę czy ulgę.

- Przeciwstawianie się i uleganie - to dynamika, zmienność strategii u pacjenta w zależności od nastrojów, uczuć i stadium choroby. To przeplatanie się aktywnych czynów z okresami totalnej rezygnacji i przygnębienia9.

Cechą charakterystyczną wielu nowotworów jest to, że w pierwszej fazie zachorowania nie wykazują żadnych objawów a pacjent nie odczuwa dolegliwości. W kolejnych jednak etapach pojawiają się różnorodne przykre dolegliwości fizyczne takie, jak silny ból w różnych miejscach, duszności, zawroty głowy, wymioty, nudności. Dolegliwości te wpływają bezpośrednio na samopoczucie chorego i jego stan emocjonalny. Do uczuć, które najczęściej towarzyszą chorobie nowotworowej należą: lęk, przygnębienie, strach, rozpacz, gniew ale i poczucie nadziei, czasem irracjonalnej.

Emocje te pojawiają się w zależności od przebiegu choroby i efektów leczenia.W odniesieniu do chorób nowotworowych często przywołuje się klasyczną już teorię adaptacji według E. Kübler-Ross (1969). Według badaczki w przebiegu ciężkiej choroby wyróżnić można pięć faz charakteryzujących się znamienną dynamiką emocjonalną.

I tak p i e r w s z a f a z a, w której pacjent dowiaduje się o chorobie charakteryzuje się odrzuceniem przez niego prawdy i izolacją. Często wypiera on informacje, które do niego docierają, thumi je. Ta psychiczna obrona związana jest z silnym uczuciem lęku i niepewności. Wszystko jest dla pacjenta nowe i odczuwa on strach.

W f a z i e d r u g i e j choroby pacjent czuje ogromny gniew i złość - pacjent obwinia cały świat za swój stan, jest zły także na siebie. Jego lęk i niepokój narastają, czuje się bardzo niepewny.

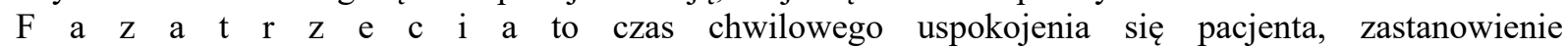
nad swoim życiem. Niekiedy pacjent próbuje pertraktować z lekarzami, z Panem Bogiem mając nadzieję na wyzdrowienie. Uczucia w tym stadium są mieszane, pacjent popada w skrajności od głębokiej irracjonalnej nadziei po zupełną rezygnację i rozpacz.

$\mathrm{F} \mathrm{a} \mathrm{z} \mathrm{a} \mathrm{c} \mathrm{z} \mathrm{w} \mathrm{a} \mathrm{r} \mathrm{t} \mathrm{a} \mathrm{to} \mathrm{faza} \mathrm{depresji.} \mathrm{Pojawia} \mathrm{się} \mathrm{ogromny} \mathrm{lęk} \mathrm{i} \mathrm{strach,} \mathrm{pacjent} \mathrm{często} \mathrm{rozpacza,} \mathrm{poddaje} \mathrm{się}$ smutkom. Niekiedy izoluje się od otoczenia.

$\mathrm{F}$ a $\mathrm{z}$ a p i ą $\mathrm{t}$ a to czas uspokojenia, pogodzenia się ze swoim losem. To etap smutku i rozpaczy, ale i wyciszenia się, pogodzenia ze swoim losem. Bywa, że pacjenci nadal czują bardzo silny lęk i popadają w totalna rezygnację ${ }^{10}$.

Każda kolejna faza wiąże się z występowaniem wielu emocji i postaw pacjenta wobec stanu, w którym się znajduje. Pewne fazy następują szybciej, inne wolniej. Wiele zależy od sposobu przekazywania diagnozy, od relacji rodzinnych pacjenta oraz systemu wsparcia i zaangażowania emocjonalnego osób bliskich.

Złożona jest również problematyka lęku. Klasyczną definicję tego zjawiska znajdziemy w znakomitej pracy A. Kępińskiego:

«Lęk byłby sygnałem ostrzegającym przed chaosem, entropią panującą w przyrodzie nieożywionej, sygnałem przed utratą własnej indywidualności (własnego porządku) [...] Lęk tkwiłby zatem w istocie życia, wynikałby z jego przeciwstawienia się prawom przyrody nieożywionej»» ${ }^{11}$. W dalszej części cytowane pracy, ten wybitny psychiatra przedstawia różne formy i rodzaje lęku, definiuje również lęk przed chorobą. Ta ogólna definicja ujmująca lęk jako sygnał ostrzegający przed chaosem doskonale wpisuje się w psychologiczny opis przebiegu choroby nowotworowej. Jest to bowiem drastyczny lęk przed zmianą życia, sposobu życia, warunkami życia czy jego przyszłością. Lęk ogólny i globalny, całościowy.

W przypadku choroby można mówić przede wszystkim o tzw. lęku biologicznym wynikającym z zagrożenia życia, z niepewnością swego stanu. Lęk biologiczny jest związany z tym co się dzieje z organizmem w kolejnych fazach choroby.

W chorobie lęk pełni także wiele innych funkcji. Jedną z nich jest ostrzeganie - sygnalizowanie, że w organizmie człowieka dzieje się coś złego. To prowadzi zwykle do wizyty u lekarza i do postawienia diagnozy. W takim rozumieniu lęk ma nas ostrzec przed niebezpieczeństwem. Lęk pełni także funkcję motywacyjno -regulacyjną, tj. stanowi o silnej motywacji do działania, motywuje do leczenia i do walki z chorobą. Jest zatem lęk pewnym motorem do mobilizacji organizmu i do współpracy pacjenta $z$ lekarzem w procesie leczenia. Jednak lęk potrafi być także wyniszczający. Pewne sytuacje związane z leczeniem i pobytem w szpitalu (a więc kolejne

\footnotetext{
${ }^{8}$ Tamże, s. 252.

${ }^{9}$ Tamże, s. 253.

${ }^{10}$ M. Jabłoński, M. Furgał i in., Miejsce psychoonkologii we współczesnej psychiatrii, «Psychiatria Polska» 2008, t. XLII, nr 5, s. 749

${ }^{11}$ A. Kępiński, Lęk, s. 81.
} 
stadia choroby, przyjęcie roli chorego, utrata niezależności, ból i cierpienie fizyczne, radykalna zmiana stylu życia) są lękotwórcze. Lęk jest najbardziej powszechnym uczuciem występującym w przebiegu każdej wyniszczającej człowieka choroby.

Chorzy przeżywają tak silne emocje, że już one same działają na nich wyniszczająco i degradująco. Pogorszenie stanu emocjonalnego pacjenta może być również związane z konkretnymi informacjami przekazywanymi w diagnozie. Szczególnie silnie działają informacje dotyczące nieoczekiwanego pogorszenia zdrowia, zastosowania wyraźnych ograniczeń dla pacjenta czy konieczność zastosowania drastycznych metod leczenia ${ }^{12}$.

Pomoc psychologiczna na oddziale onkologicznym. Każda choroba i pobyt w szpitalu to sytuacja niezwykle stresująca. Dlatego też niezbędna jest pomoc psychologa - jego rozmowa oraz wsparcie. Pacjenci chcąc zniwelować stres i lęk radzą sobie na różne sposoby. Bardzo często ich przejawem walki jest stosowanie różnorodnych mechanizmów obronnych, a więc nieświadomych działań mających na celu niedopuszczenie do świadomości wszelkich sygnałów chorobowych. Najczęściej występującymi mechanizmami w życiu chorych są:

1) wyparcie i thumienie i nieświadome «oszukiwanie się», że nie jest się chorym, że dotyczy to kogoś innego,

2) bagatelizowanie, minimalizowanie - ten sposób radzenia sobie polega na pomniejszaniu objawów: znaczenie samej choroby (np. «to tylko mała operacja i wracam do domu»),

3) racjonalizacja: to wytłumaczenie sobie w najwygodniejszy i najmniej zagrażający sposób znaczenia choroby, jej objawów i leczenia (np. «to tylko choroba, wiele osób na to choruje») ${ }^{13}$.

Poza powszechnym stosowaniem mechanizmów obronnych mówić można także o pewnych stylach lub formach zmagania się ze stresem choroby. Jest to indywidualna strategia działań mająca za zadanie kojąco wpływać na takie kategorie związane ze stresem, jak zagrożenie, bezradność czy niepewność. Ponieważ klasyfikacji stylów i form radzenia sobie ze stresem choroby jest wiele, przyjęłam w poniższej pracy szczegółowy podział form wg Byrne'a, Krohne'a i Millera. Są to:

a) Przemiana - sposobem walki ze stresem i chorobą jest dokonywanie zmian w stosunku do samego siebie, hierarchii wartości i celów życiowych oraz własnego zachowania.

Choroba jest zatem odbierana przez chorego jako nowy, lepszy rozdział w życiu i tym samym stres pełni tu rolę mobilizującą do działania.

b) Obwinianie siebie - to zachowania polegające ma obarczaniu odpowiedzialnością za swój stan. Jest to pewna forma autoagresji - wyrzucanie sobie, że doprowadzono się do choroby, robienie sobie wyrzutów. Zachowanie to ma na celu wyładowanie negatywnych emocji oraz specyficznie odczuwanego stresu.

c) Koncentracja na problemie - to forma aktywnej walki z chorobą, mobilizacji w pokonywaniu stresu i choroby. Chory podejmuje zdecydowane, racjonalne i planowane działania, analizuje dokładnie sytuację.

d) Ucieczka - fantazjowanie - forma nawiązują swoim zachowaniem do mechanizmów obronnych, a więc unikanie problemu, ucieczka w marzenia, oderwanie się od rzeczywistości, w tym od stresujących przeżyć.

e) Wzorowanie się na innych - to podpatrywanie tego w jaki sposób inni chorzy radzą sobie ze stresem choroby i powielanie zachowań, które uznaje się za sprawdzone.

f) Rezygnacja - to forma biernego zachowania polegającego na pogodzeniu się ze swoim losem oraz całkowitej rezygnacji z aktywnych działań rozwiązania problemu.

g) Odreagowanie - to forma często spotykana u pacjentów zwłaszcza w drugim stadium choroby polegająca na rozładowywaniu napięcia psychicznego i silnych negatywnych emocji poprzez ich ekspresję czy agresję.

h) Kontrolowanie emocji - to świadome opanowanie i stłumienie własnych negatywnych emocji, eliminowanie ich w działaniu. Pacjent dąży do zachowania równowagi emocjonalnej ${ }^{14}$.

Wyżej wymienione formy walki ze stresem choroby należą do taktyk osobistych i indywidualnych. Problem pomocy psychologicznej w tej sytuacji jest jednakże bardziej rozwinięty. Pomoc psychologiczna obejmuje także szereg działań «z zewnątrz», a więc podejmowanych przez samego psychologa. Z pomocy tej skorzystać powinien sam pacjent, ale również jego rodzina, znajomi i wszyscy, których w pewien sposób dotknęła ta choroba. Do form działań psychologicznych należą: psychoterapia, interwencja kryzysowa oraz poradnictwo psychologiczne.

1. Psychoterapia na oddziale onkologicznym: na oddziale szpitalnym psycholog może prowadzić różnorodne odmiany psychoterapii, w zależności od zapotrzebowania i swoich kompetencji. Pomoc ta dostosowywana jest do etapów choroby i leczenia. Cele, jakie stawia sobie terapeuta w swojej pracy, to:

- pomoc w akceptacji rozpoznania, motywowanie do leczenia,

- przygotowanie pacjenta do zabiegu, zmniejszenie jego lęku,

- przygotowanie chorego do zmian, jakie zaszły w jego organizmie po operacji,

- pomoc w rehabilitacji i powrocie do codzienności po udanym leczeniu,

- pomoc w obronie przed lękiem różnego pochodzenia (przed nowotworami, przerzutami itp.),

${ }^{12}$ A. Leksowska, I. Jaworska, P. Gorczyca, Choroba somatyczna jako wyzwanie adaptacyjne dla czlowieka, «Folia Cardiologica Excerpta» 2011, T.6, nr 4, s. 246.

${ }^{13}$ H. Sęk, Wprowadzenie do psychologii klinicznej, s. 244.

${ }^{14}$ T. Turuk-Nowak, Pomoc psychologiczna pacjentom onkologicznym [W:] D. Kubacka-Jasiecka (red.), «Zmagając się z chorobą nowotworową», s. 189-190. 
- pomoc w doraźnym odreagowaniu napięcia emocjonalnego i lęku, wsparcie psychiczne ${ }^{15}$

W oparciu o znajomość przebiegu choroby pacjenta należy stworzyć indywidualny program psychoterapii. Do najczęściej wybieranych metod psychoterapii chorych należą:

a) Psychoterapia aktywna objawowa - odpowiednia w każdej fazie choroby i leczenia, jej celem jest umożliwienie pacjentowi reagowania, ujawnienia silnych emocji poprzez mówienie o tym co boli, o swoim lęku, obawach, o gniewie, nadziei. Jest to wstęp do dalszej terapii.

1. Psychoterapia racjonalna - funkcją tej psychoterapii jest przede wszystkim informowanie pacjenta o przebiegu, leczeniu i skutkach jego choroby oraz motywów mobilizacji pacjenta do zajęcia aktywnego stanowiska wobec choroby. Celem tej psychoterapii jest również przygotowanie pacjenta do trudnej operacji oraz innych obciążających form leczenia (np. chemioterapii).

2. Relaksacja - to metoda często stosowana i polecana wśród chorych. Jej głównym celem jest redukcja stanów napięcia i lęku, poprawa samopoczucia oraz złagodzenie dolegliwości bólowych spowodowanych chorobą. Często pacjenci zdobywają umiejętność samodzielnego ćwiczenia relaksacji.

3. Wizualizacja - metoda ta polega na wyobrażaniu sobie przez pacjenta własnego ciała aktywnie walczącego z nowotworem. Dzięki temu pobudzeniu ma ulec układ odpornościowy oraz wzrost aktywności immunologicznej. Dzięki seansom wizualizacji pacjent uczy się żyć ze swoją chorobą, akceptuje jej objawy, ale równocześnie uczy się kontrolować swój organizm i aktywizować się w walce z chorobą.

4. Psychoterapia rodzin - metoda ta polega przede wszystkim na pracy terapeuty z osobą bliską lub z całą rodziną. Na spotkaniach omawiane są metody leczenia, skutki uboczne, możliwości pomocy itp. Celem psychoterapii systemu jest także pomoc rodzinie w opanowaniu własnych trudności emocjonalnych, ułatwienie komunikacji między rodziną a pacjentem oraz pomoc w zrozumieniu sytuacji chorego, rozpoznanie jego potrzeb.

5. Autopsychoterapia - to metoda stymulująca pracę nad sobą, ćwiczenie technik pomagających zwalczyć stres i napięcie emocjonalne. To wyrabianie w sobie woli walki i przetrwania oraz umiejętność radzenia sobie w sytuacjach kryzysowych. Wszystkie te działania mają na celu zmotywowanie chorego do przyjęcia odpowiedzialności za siebie i do podjęcia świadomej walki z rakiem ${ }^{16}$.

- Interwencja kryzysowa - ten rodzaj działalności psychologicznej sprawdza się głównie w nagłych traumatycznych wydarzeniach życiowych. Do takich wydarzeń należy bez wątpienia informacja o ciężkiej chorobie, o przerzutach i niepewnym rokowaniu. Każda z tych sytuacji wymaga szybkiej reakcji psychologicznej. Do działań interwencyjnych należą tu:

- udzielanie wsparcia pacjentowi oraz jego rodzinie, wysłuchanie i nawiązanie kontaktu,

- pomoc w zrozumieniu i zaakceptowaniu sytuacji,

- pomoc w zorganizowaniu szerokiej pomocy (np. konsultacji z lekarzem).

Psycholog powinien dostosować pomoc do indywidualnej sytuacji pacjenta oraz do jego potrzeb ${ }^{17}$.

Poradnictwo psychologiczne - to inna równie istotna metoda pomocy stosowana przez środowisko psychologów. Z porady psychologicznej chory może korzystać na każdym etapie leczenia i choroby. Psycholog stara się wraz z chorym rozwiązać jego problemy i tym samym obniżyć jego bezradność i niepewność.

Wnioski. Zaprezentowane klasyfikacje i modele teoretyczne będące efektem pracy badawczej przede wszystkim lekarzy i psychologów zdrowia pozwalają na przedstawienie najważniejszych wniosków. Współcześnie choroba nowotworowa jest ujmowana holistycznie co oznacza, że jej leczenie powinno obejmować zarówno ciało jak i umysł, psychikę. Sfera psychiczna choroby obejmuje takie ważne aspekty jak:

- przeżywane przez pacjenta emocje, w tym głównie silny lęk biologiczny, egzystencjalny,

- etapy przeżywania choroby i kolejne stadia oswajania się z nią,

- subiektywny obraz choroby czyli to co buduje jego reprezentację poznawczą,

- psychologiczne mechanizmy obronne radzenia sobie z chorobą, np. racjonalizacja czy wyparcie,

- postawy chorego wobec stanu zdrowia oraz motywację do leczenia,

- psychoterapię i inne metody wspierania psychologicznego.

Choroba nowotworowa wymaga leczenia interdyscyplinarnego, stąd też coraz większą rolę w jej leczeniu pełni psycholog lub psychoonkolog. Powstają również grupy wsparcia dla chorych i rodzin pacjentów onkologicznych. W pracach badawczych podejmowane się też inne ważne aspekty psychologiczne, takie jak radzenie sobie ze stresem czy znaczenie stresu w etiologii choroby onkologicznej. Wiele prac poświęcono technikom wspierania oraz psychoterapii ${ }^{18}$. Z uwagi na to, że ludzie coraz częściej chorują na różne formy i lokalizacje nowotworu, trzeba mieć nadzieję że badania te będą bardzo intensywne.

Każdy człowiek, który znalazł się w sytuacji choroby nowotworowej odczuwa olbrzymi stres, lęk i napięcie

\footnotetext{
${ }^{15}$ T. Turuk-Nowak, Pomoc psychologiczna pacjentom onkologicznym [W:] D. Kubacka-Jasiecka (red.), «Zmagając się z chorobą nowotworową», s.190.

${ }^{16}$ Tamże, s. 191.

${ }^{17}$ Tamże, s. 191.

${ }^{18}$ Zob. M. Stańko, Arteterapia jako metoda profesjonalnej pomocy chorym na nowotwory, «Współczesna Onkologia» 2008, nr 12,3; M. M. Jabłoński, J. Kozaka, W. Rachel, Czy można mówić o specyfice psychoterapii i superwizji onkologicznej?, «Psychoonkologia» $2015, \mathrm{nr} .3$.
} 
emocjonalne. Jego przyszłość staje się niepewna, wszelkie marzenia i plany nagle stają się nierealne. Dlatego tak ważną osobą na oddziale jest psycholog. Niekiedy jest on jedynym człowiekiem do którego chory ma zaufanie, do którego zwraca się z pytaniami, któremu ma odwagę opowiedzieć o swoim lęku. Tym samym psycholog wkraczając w świat chorego towarzyszy mu w jego cierpieniach, razem z nim stawia czoła chorobie i jej następstwach.

Liczne modele prezentujące etapy przystosowania się do choroby, mimo że bazują na wieloletnich badaniach, to jednak tylko teoretyczny konstrukt. Każdy chory przeżywa swoje etapy i swoją chorobę po swojemu i indywidualnie. Warto jednak pamiętać, jak pisze Kopczyńska - Tyszko, «że przybliżenie czytelnikowi przeżyć chorych na raka jest zadaniem bardzo trudnym ${ }^{19}$. Nikt z nas, kto nie doświadczył tak ciężkiej choroby, prawdopodobnie nie jest w stanie sobie nawet wyobrazić siły lęku, który odczuwa człowiek, który nie jest pewny swojego losu. Jak dodaje Kopczyńska, «Intensywność tych stanów emocjonalnych, ich zmienność, a także ich mieszanina sprawiają, że życie emocjonalne chorych na raka staje się często straszliwym psychicznym «holocaustem», w którym nie ma granicy miedzy bólem fizycznym i psychicznym ${ }^{20}$.

\section{Bibliografia:}

1. Bąk- Sosnowska M., Choroba w życiu człowieka, [W] A. Trzcieniecka- Green (red.) «Psychologia. Podręcznik dla studentów kierunków medycznych», Universitas, Kraków 2006.

2. Bishop G. D., Psychologia zdrowia, Wydawnictwo ASTRUM, Wrocław 2000.

3. Heszen-Klemens I., Psychologia medyczna. Główne kierunki badań. Wydawnictwo Uniwersytetu Śląskiego, Katowice 1983.

4. M. M. Jabłoński, J. Kozaka, W. Rachel, Czy można mówić o specyfice psychoterapii i superwizji onkologicznej?, «Psychoonkologia» 2015, nr.35

5. Jarosz M., Psychologia lekarska. Państwowy Zakład Wydawnictw Lekarskich, Warszawa 1983.

6. Kępiński A., Lęk, Państwowy Zakład Wydawnictw Lekarskich, Warszawa 1977.

7. Kopczyńska-Tyszko A., Reakcje emocjonalne chorujących na nowotwór [W:] D. Kubacka - Jasiecka (red.), Zmagając się z choroba nowotworowa, Wydawnictwo Uniwersytetu Jagiellońskiego, Kraków 1999.

8. Kubacka - Jasiecka D., Problematyka lęku i zmagania się z lękiem w chorobach nowotworowych [W:] D. Kubacka-Jasiecka (red.), Zmagając się z choroba nowotworowa, Wydawnictwo Uniwersytetu Jagiellońskiego, Kraków 1999.

9. Kulczyki M., Psychologiczne problemy czlowieka chorego. Ossolineum, Wrocław 1971.

10. Leksowska A., Jaworska I., Gorczyca P., Choroba somatyczna jako wyzwanie adaptacyjne dla czlowieka, «Folia Cardiologica Excerpta» 2011, T.6, nr 4.

11. Łosiak W., Proces zmagania się ze stresem choroby przez pacjentów [W:] D. Kubacka-Jasiecka (red.), Zmagając się z choroba nowotworowa, Wydawnictwo Uniwersytetu Jagiellońskiego, Kraków 1999.

12. Łosiak W., Subiektywny obraz choroby u pacjentów [W:] D. Kubacka-Jasiecka (red.), Zmagając się z choroba nowotworowa, Wydawnictwo Uniwersytetu Jagiellońskiego, Kraków 1999.

13. Nęcki Z., Górniak L., Przekonania i postawy spoteczne wobec chorób nowotworowych, [W:] D. Kubacka-Jasiecka (red.), Zmagajac się z choroba nowotworowa, Wydawnictwo Uniwersytetu Jagiellońskiego, Kraków 1999.

14. Pawlęga J., Medyczny obraz choroby nowotworowej [W:] D. Kubacka-Jasiecka (red.), Zmagajac się z choroba nowotworowa. Wydawnictwo Uniwersytetu Jagiellońskiego, Kraków 1999.

15. Sęk H., Wprowadzenie do psychologii klinicznej. Wydawnictwo Naukowe «Scholar», Warszawa 2003.

16. Stańko M., Arteterapia jako metoda profesjonalnej pomocy chorym na nowotwory, «Współczesna Onkologia» $2008, \mathrm{nr} 12,3$.

17. Turuk-Nowak T., Pomoc psychologiczna pacjentom onkologicznym [W:] D. Kubacka-Jasiecka (red.), Zmagając się z choroba nowotworowa. Wydawnictwo Uniwersytetu Jagiellońskiego, Kraków 1999.

18. Wrona-Polańska H., Psychologiczne aspekty informowania pacjentów o chorobie [W:] D. Kubacka-Jasiecka (red.), Zmagając się z chorobq nowotworowa. Wydawnictwo Uniwersytetu Jagiellońskiego, Kraków 1999.

\footnotetext{
${ }^{19}$ A. Kopczyńska-Tyszko, Reakcje emocjonalne chorujacych na nowotwór [W:] D. Kubacka-Jasiecka (red.), Zmagając się z choroba nowotworowa, s. 125.

${ }^{20}$ Tamże, s. 125.
} 